\title{
Diagnosis of rubella virus using antigen-conjugated Au@Pt nanorods as nanozyme probe [Corrigendum]
}

Zhang T, Tian F, Long L, Liu JB, Wu XC. Int JNanomedicine. 2018;13:4795-4805.

Page 4795, the author affiliations are listed incorrectly, the correct affiliations are shown below.

Tao Zhang ${ }^{1,2}$

Fang Tian $^{3}$

Lin Long $^{1,2}$

Jianbo Liu ${ }^{1}$

Xiaochun $\mathrm{Wu}^{4}$
${ }^{1}$ College of Opto-electronic Engineering, Zaozhuang University, Zaozhuang, China; ${ }^{2}$ Department of Clinical Laboratory, Zaozhuang Municipal Center for Disease Control and Prevention, Zaozhuang, China; ${ }^{3}$ Department of Clinical Laboratory, Zaozhuang Municipal Maternal and Child Health Hospital, Zaozhuang, China; ${ }^{4}$ CAS Key Laboratory of Standardization and Measurement for Nanotechnology, National Center for Nanoscience and Technology, Beijing, China
International Journal of Nanomedicine

\section{Publish your work in this journal}

The International Journal of Nanomedicine is an international, peerreviewed journal focusing on the application of nanotechnology in diagnostics, therapeutics, and drug delivery systems throughout the biomedical field. This journal is indexed on PubMed Central, MedLine, CAS, SciSearch ${ }^{\circledR}$, Current Contents ${ }^{\circledR} /$ Clinical Medicine,

\section{Dovepress}

Journal Citation Reports/Science Edition, EMBase, Scopus and the Elsevier Bibliographic databases. The manuscript management system is completely online and includes a very quick and fair peer-review system, which is all easy to use. Visit http://www.dovepress.com/ testimonials.php to read real quotes from published authors. 